\title{
The Status of Internet, Computer and Mobile Phones in Development of Sport Corporation in Iran
}

\section{Mahbobeh Jafarzadeh Zarandi ${ }^{1}$, Emadodin Sayadi ${ }^{1}$, Azam Ziaadini $^{2}$, Reza Eskandari Nasab ${ }^{3}$}

1. Department of Sport Management, Kerman Science and Research Branch, Islamic Azad University, Kerman, Iran

2. Assistant Professor, Islamic Azad University of Zarand, Zarand, Iran 3. M.A of sports Management, Islamic Azad University, Science and Research Branch Mashhad, Mashhad, Iran

Corresponding Author: Mahbobehjafarzadeh@yahoo.com

DOI: 10.6007/IJAREMS/v3-i1/568 URL: http://dx.doi.org/10.6007/IJAREMS/v3-i1/568

\begin{abstract}
As modern technologies are necessary tools for any entrepreneur, investigation of various opportunities needs more application of such modern technologies. Method Implementation The research was Survey. The population under study involves all manufacturers of sport accessories in Iran (N=300) out of which 169 cases are selected randomly using Morgan table. Khosrovani standard questionnaire (2012), derived from Histrich and Peter's questionnaire, with confirmed reliability and stability have also been used in order to collect data. The reliability coefficient of the present study has been calculated using Kronbach method $(a=0.89)$ and its stability has also been defined using numerical sigma 0.85 under supervision of wellexperienced experts and professionals. To describe the data, statistical descriptive methods have been used (abundance distribution table, average, standard deviation and abundance graphs) and illative data (repetitive variance analysis) alongside SPSS 20 software on a meaningful $P<0.05$ have been used.
\end{abstract}

Key words: internet, computer, mobile phone, entrepreneurship, sport

\section{Introduction}

Over the last two decades, much of the developed world has been transformed by Information and Communication Technologies (ICTs). These technologies made possible significant productivity gains in business through enabling great changes in how processes are carried out, for example reducing labor costs, increasing proximity to customers and standardizing products and brands (Gibbs et.al, 2003). Information and communication technologies (ICT) include tools, devices, and resources used to communicate and to create, manage, and share information. This includes hardware (computers, modems, and mobile phones), software (computer programs, mobile phone applications) and networks (wireless communications, internet) (Ballon et.al, 2008). Tinio defines ICT as a "diverse set of technological tools and resources used to communicate, and to create, disseminate, store, and manage information." 
These technologies include computers, the Internet, broadcasting technologies (radio and television), and telephony (Tinio, 2002).

ICT is defined as processing knowledge and its application in production, process, and transformation of information (Karamipour, 2003).IT can also be defined as the process of collecting, organizing, saving, broadcasting, and using information in the forms of sound, picture, graphic, text, and digit by using computer and other communication tools (Rais Dana, 2002). Information technology is a combination of communication, reservation, processing and multimedia capabilities. The main role played by communicative network is called ICT (Rudestam et.al, 2004). Information and communication technologies have been the touch stone of change and evolution in the last decade. Not only information technology has create new job opportunities, but also it has caused changes in many other careers as well; still many believe that automation has made considerable amount of redundancy. But does information technology bring upon new job opportunities or more redundancy? Is information technology trend and its impact on job opportunities in different nationalities something which can be traced or is it that individuals are carried on the wave towards an ambiguous destination in the middle of nowhere? And ultimately can information technology be the key to less UN employment among the educated youth? (Baqeri et.al, 2012). The world of future will be totally different from what we see today and will be led by capable individuals who are familiar with the know-how of information technology and accordingly base their institutions and social interactions on such concept. Therefore it is of utmost importance to flourish talents and creative thoughts so that they could become leaders of the world to come (Montazer, 2002). Internet, as an important visualization of the information technology, plays a vital role in the evolution of globalization. Despite the very short life of internet, many governments and international companies are it small or big, and even small families use it to meet their everyday needs. Parallel to the application of information technology in all dimensions of life, the world is also rapidly moving towards an information society (Salimi et.al, 2009). On the other hand internet has enabled sports fans all over the world to access up-to-date date about their favorite teams. Today sport fans are more pleased using internet as even numerous TV channels cannot meet their ever-increasing needs (Madhoshi and Safari Nejad, 2004). Entrepreneurs' awareness of the rapid growth of the Internet in recent years has led to the conception of many ideas for business startups, where the Internet has either a central or supporting role in how the business will be developed. Until the recent "dot com" crash, the eagerness of investors to participate in the financial support of any kind of Internet based or supported new venture business proposal has been staggering, and the launch and high public profile of these startups may have encouraged others to think of ways to get a share of the action (Mcqueen, 2010). A business plan is an important document that transforms embryonic ideas into a well thought out prospectus for potential investors and other financing sources. The process of developing an entrepreneurial idea into a business plan that is of the quality to attract the interest of prospective investors and financiers entails a significant amount of effort, and requires the entrepreneur to understand markets, market shares, sales projections, cash burn rates, and many other aspects of starting a business (Rudestam et.al, 2004). The effort put into the business plan development is often rewarded with a clearer view by the entrepreneurs of the potential risks and rewards of the venture, and forms the basis on which constructive comments and suggestions can be solicited and received from external advice 
givers. Business plans developed by prospective entrepreneurs thus provide a window through which to examine the industries and business areas which these entrepreneurs feel have potential for a business start-up (Baqeri et.al, 2012). In addition, these plans indicate to what extent the entrepreneurs envisage using the Internet as a main focus or in a supporting role for their business idea. Business plan competitions are designed to encourage, motivate, and assist prospective entrepreneurs to work through a process in which they develop and refine their ideas into documents that can be used to seek investment finance (Salimi et.al, 2009).

Whether new ventures have a significant Internet-based component or not, entrepreneurs might be generally characterized as interested in new ideas and ways of doing things, and are likely to be well represented in the growing proportion of the population who are regular users of the Internet. For those prospective entrepreneurs who are not necessarily expert in IT or Internet technologies, there may be many who would be interested in including an Internet component in a more traditional new venture startup (Mcqueen, 2010).

The Internet was intended, and did become the major communications vehicle for the competition, and useful information such as updates to contest rules, and copies of seminar slides were posted frequently to the website. Through efficient roles in businesses, sports entrepreneurs can guarantee health and participation in all parts of the society. As a result they look forward to more conceptualized strategies to improve such businesses (mondalizade and honary, 2010). The growing importance of entrepreneurship for today's occupational careers is generally acknowledged (Hisrich et.al, 2007). Engaging in entrepreneurship is seen as an adaptive vocational behavior in view of the diverse challenges, occupational risks, but also opportunities that come along with the massive economic, technological, and social change those societies across the globe are facing today (Audretsch, 2007). Furthermore, entrepreneurship, and the creation of innovative new ventures in particular, is regarded as a crucial contributor to economic development (e.g., through the exploitation of innovations) as well as to societal wealth (e.g., through job creation). However, there is still an ongoing debate on what actually is "the essence of being 'entrepreneurial'" (Krueger, 2007). The secret to knowledge survival however lays in expansion and survival of computer databases. Databases are organized combinations of data capable of being searched and accessed within a click. Nowadays software databases such as common office package are well-known all over the world. Yet in the field of sport, a giant, reliable database can only emerge with computers all over the world connected to each other, namely networking. More competitions in business make it difficult for businesses to survive. This is more evident in small and medium-size businesses where information technology and interactions seems crucial (Akbary, 2005). The mobile landscape has evolved from devices purely built for telephone calls and text messaging to sophisticated pocket computers called smartphones, while mobile Internet connections have shifted from slow and costly connections towards $3 G$ broadband access. At the same time, new ways in which consumers use the mobile internet and in which mobile service applications have emerged, breaking the traditional dominance of mobile network carriers over service delivery (Gerum et.al, 2004).New information and communication technologies (ICTs) such as computers, mobile phones, email and the Internet are providing a new challenge for the business community in developing countries. Unfortunately, for many businesses even a telephone line connection remains unobtainable. However, the costs of access to new communication technologies - such as mobile phones - are falling rapidly, and investment in 
such technologies may benefit your business. Mobile communications means communicating without the need for a fixed phone line. High frequency radio signals are broadcast from a network of transmitters organised geographically into cells on the ground. The signals can carry computer data and fax messages as well as conversation. The mobile user can move around freely and use their phone as long as they are in range of a transmitter. Phone conversations and information are converted into digital format (the same way as data is stored on a computer). Messages are transmitted using a global standard. It is usually based on GSM technology (Global System for Mobile Communications).Experts believe that in 2014 more internets will be used via cell phones rather than personal computers. Mobile phones are no more considered as luxury assets owned by selected few, rather they have facilitated communication. In fact they believe that cell phones, which used to be magical devices, are vital tools of present life. That's why mobile phones are significantly important in facilitating interactions, transmission of data, more business deals and ultimately making more money. In our country cell phones are predominantly used for calls, i.e. not much has been done to take advantage of this tool in financial interactions, however experts believe that upon emergence of the third generation of mobile phones to Iran and accordingly more competition among service providers, there will be more added value and in turn more development in all economic fields (Fathian and Mahdavinoor, 2008). Entrepreneurship in sport can be best defined as exploitation of available opportunities in sport, opportunities which on surface could be seen as shortages or threats or easily be ignored. Creating new job opportunities in sport services and products and converting threats to opportunities for the sake of creating more employment are concerns which need attention in this field. Sport is a highly recognized phenomenon and upon being valued could be used as a valuable means towards entrepreneurship (Froghipoor, 2007). wenhong chen (2006) in a study entitled the impact of internet use on transnational entrepreneurship, upon investigating participatory observations and interviews in Toronto and Beijing, believes that application of internet has a positive impact on entrepreneurs. He believes that internet is of utmost importance for searching and mobilization of sources. Lai and Chen (2009) in their study of the role and impact of e-business in particular to improve the efficiency and competitiveness of the business environment from the create place of job opportunities supplement for individuals paid. The results of their study demonstrated the positive impact of e-business using the computer. In this research, a field study was conducted at six companies in Taiwan. Malhotra et .al (2012) in a study entitled How mobile phones, computer and internet can catalyze woman's entrepreneurship found that mobile phones more than computer and Internet can help women's entrepreneurs While women used all shapes of information and communication technologies. Capability and ease of use of mobile phones has caused that mobile phones convert to a friendly tools that support the business growth. As a result the present study has focused on the lack of unanimous trends in investigations and vacuums, impact of internet, computer and mobile in the field of sport in Iran and tries to respond to the question: What impact do internet, computer and mobile have on the development of sports corporation in Iran.

\section{Methodology}

Regarding the concept of the study, it is of practical nature and uses survey methods. The statistical population involves all manufacturers of sport accessories in Iran ( $N=300)$. The data needed for the study has collected from the state website of the Ministry of Industries, Mines 
and Commerce and sport database of Iran in 2012. Among the 300 companies, 169 ones were selected using Morgan table. Random selection was applied while select in the companies. The questioner used in the study has been inspired by Khosrovani Fard questioner 2012 which in turn was derived from Histrich and Peter 2002 whose stability and reliability were 0.89 and 0.85 successively. The present questionnaire comprises all items related to entrepreneurship in four main Ares namely creation of business concept, feasibility of business, startup of new businesses and evaluation and expansion of businesses. There are 28 questions in the questionnaire out of which 3 questions relate to the creation of business concept, 3 to feasibility of business, 15 to startup of new businesses and 5 to evaluation and expansion of businesses. (In the four sections Licert 5 -value scale i.e. very much to very little was used).To analyses the data descriptive and illative methods (repetitive variance) as well as SPSS $_{20}$ software (on a meaningful surface of $\mathrm{P}<0.05$ ) were used. In order to organize, summarize and classify the scores and to describe the amounts, the abundance distribution table, percentages and calculation of scattering indexes such as mean, standard deviation and graphs, descriptive statistics was used.

\section{Theory of the study}

There is difference among modern technologies (internet, computers and mobile phones) in the creation of entrepreneurship opportunities

\section{Findings}

Table 1 shows the mean and standard deviation of the life of active manufacturers of sport accessories in Iran.

Table 1- standard deviation of the life of active manufacturers of sport accessories

\begin{tabular}{llllll}
\hline Alternative & Number & Least & Most & Mean & $\begin{array}{l}\text { Standard } \\
\text { deviation }\end{array}$ \\
$\begin{array}{l}\text { Work } \\
\text { experience }\end{array}$ & 169 & 2 & 48 & $19 / 14$ & $11 / 217$ \\
\hline
\end{tabular}

Figure 1 shows the level of education of the managers of manufacturers of sport accessories in Iran. As it is seen most managers possess diploma (51\%) and others successively possess Bachelor (24.8\%), Associate (19.1\%) and Master and over (5.1\%).

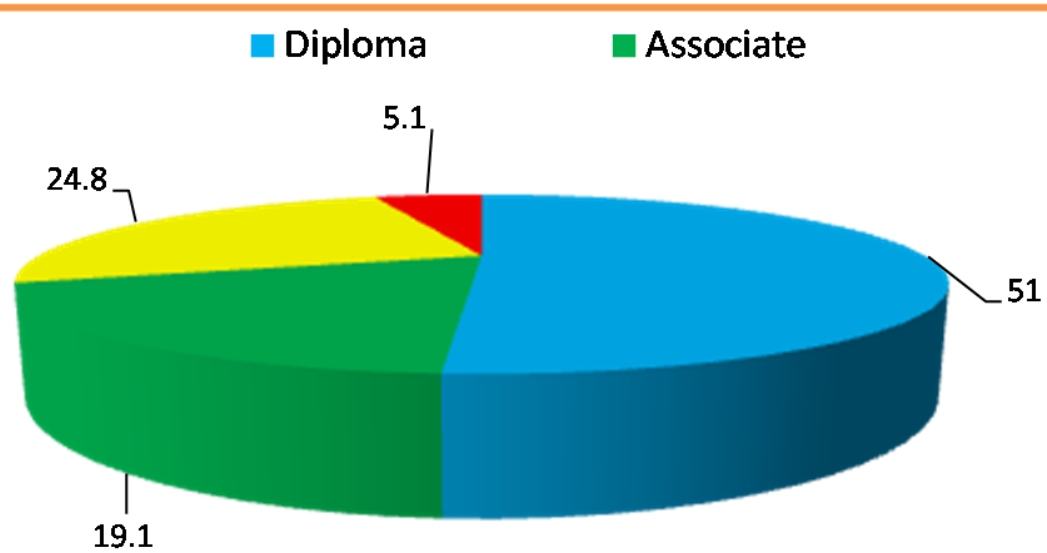


Figure 1 - the level of education of the managers

Figure 2 shows the managers' fields of study in percent, revealing that the majority of them have studied in non-sports

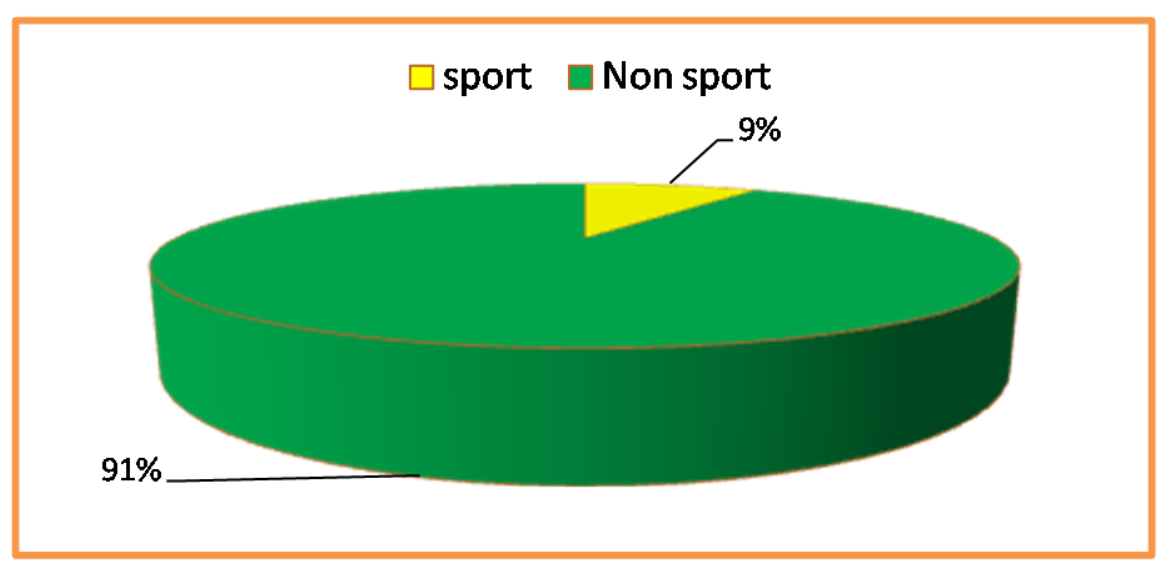

fields.

Figure 2 - the managers' fields of study in percent

The results derived from studying sport manufacturing companies' ownership type reveal that all are privately owned.

The descriptive statistics related to companies being studied reveal that the majority of them are join ventures.

Table 2- Types of companies in the study

\begin{tabular}{ccc}
\hline Type & N & Percentage \\
Corporate partnership & 7 & 4.14 \\
Ltd & 38 & 22.48 \\
Joint & 103 & 60.94 \\
LLP & 12 & 7.10 \\
Other & 9 & 5.32 \\
Total & 169 & 100 \\
\hline
\end{tabular}

\section{Describing specified data}

Figure 3 shows that about $14.7 \%$ of manufacturers possess an IT and/or communication officer while others lack such posts. 


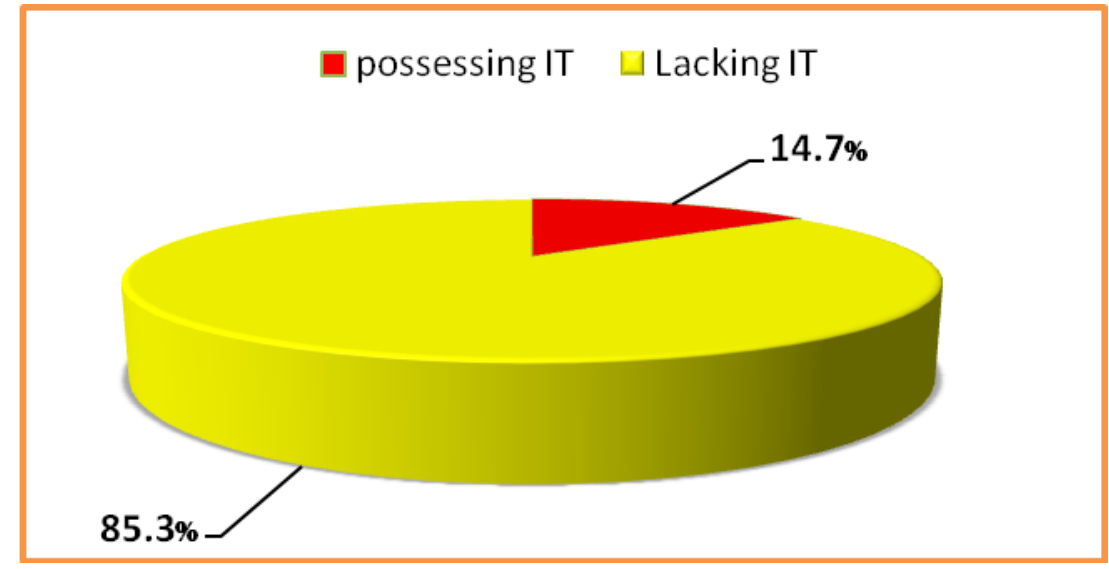

Figure 3 - IT and/or communication officer

Also by looking at the application of interest in the sport manufacturing sector of Iran one could see that about $67.5 \%$ of the manufacturers are connected to the internet while others work off line.

Analysis of theory Hypothesis

There is a difference between entrepreneurs' concept of the role of modern technology (internet, computers and mobile phones) in creating entrepreneurial opportunities and scores derived from this study.

Table 3 shows statistics derived from Muchly's test so order to evaluate approx. chi-square and as there is a meaningful level of $\mathrm{P}<0.05$ Hain Flat correction coefficient $\mathrm{df}$ has been used.

Table 3-Muchly's test

Factor 1

$\begin{array}{cccccc}\text { Lower } & \begin{array}{c}\text { Huynh } \\ \text { feldt }\end{array} & \begin{array}{l}\text { Green } \\ \text { house } \\ \text { geisser }\end{array} \quad \text { Df } & \text { sig } & \begin{array}{c}\text { Approx. } \\ \text { chi- } \\ \text { square }\end{array} & \text { Wauchly's } \\ & & & & \end{array}$

Within subject effect

0.50

0.81
0.75

$\begin{array}{ccc}0.80 & 1 & 0.00 \\ & 6 & 1 \\ & 8 & \end{array}$

Therefore, based on Hain Flat correction co efficiencies (table 4), the mentioned coefficient becomes meaningful leading to confirmation of different item means. Therefore zero theory is unacceptable and it could be stated that components of modern technology (internet, computers and mobile phones) have in between a meaningful difference.

\begin{tabular}{lcccc}
\multicolumn{5}{c}{ Table 4-F results } \\
\hline Source & $\mathrm{df}$ & $\mathrm{F}$ & Mean square & Sig \\
Huynh feldt & 2 & 39.79 & 9.22 & 0.001 \\
\hline
\end{tabular}

To pair compare the alternatives Bounferoni adjustment test has been used. 
Table 5 - Bounferoni test related to comparison of modern technologies

\begin{tabular}{|c|c|c|c|c|c|}
\hline \multirow{2}{*}{\multicolumn{2}{|c|}{ Factor }} & \multicolumn{4}{c|}{ Criterion Score=3 } \\
\cline { 3 - 6 } & df & $\begin{array}{c}\text { Mean } \\
\text { diffrence }\end{array}$ & Sig & Std.error \\
\hline \multirow{2}{*}{ Internet } & Computer & 168 & 0.22 & 0.001 & 0.04 \\
\cline { 2 - 6 } & Mobile phones & 168 & 0.50 & 0.001 & 0.06 \\
\hline \multicolumn{2}{|c|}{ Computer Mobile phones } & 168 & 0.28 & 0.001 & 0.05 \\
\hline
\end{tabular}

As it is seen in table 5, the Bounferoni test related to comparison of modern technologies, the pair comparison of alternatives reveal a meaningful difference between components of modern technologies (internet, computers and mobile phones).

\section{Discussion}

It seems that internet has an accelerating role in the entrepreneurial field and regarding its role in lowering costs in the marketing sector and its capability of providing $24 / 7$ access to products and services, it is considered as an important item in new businesses. By accessing the internet. Entrepreneurs could take advantage of its rich sources of information, as well as introducing and advertising their services and products. This in turn could, to a considerable degree, lower the costs of printing and distributing catalogues and brochures by delivering the information within a click of mouse. As it is seen in the results, on the side of entrepreneurs there is a meaningful difference between the role of the internet in providing entrepreneurial opportunities in sport and real scores; as a result wenhong Chen 2006, upon investigating participatory observations and interviews in Toronto and Beijing, believes that application of internet has a positive impact on entrepreneurs. He believes that internet is of utmost importance for searching and mobilization of sources. The results coming from this study are consistent with the results coming from wenhong Chen's investigation. A study done by Malhotera et.al in 2012 show those mobile phones could be more useful to businesses than internet and computers. Malhotera's study does not agree with such results. As it is shown in this study the role of internet exceeds that of other components and therefore it is suggested that entrepreneurs in the field of sport be educated on the subject in order to take advantage of the internet in their activities.

With the rapid development of modern information technology, computer and networking applications have been widely used in various fields, gradually changing people's work, study and life, especially in education (Pelgrum, 2001). The most significant production factor within the process of the formation of information society is information. The countries which are able to accommodate themselves to the rapid changes in the world and make their individuals equip with the qualifications arise from this new environment requirements, access, produce and use information will be able to be influential and successful in the 21st century. The slogans of "Computer for everyone", "Internet for everyone" and "E-government" have already been interiorized by all the societies aiming to become an information society (Keser, 2004). 
Databases are organized combinations of data capable of being searched and accessed within a click. Nowadays software databases such as common office package are well-known all over the world. Yet in the field of sport, a giant, reliable database can only emerge with computers all over the world connected to each other, namely networking. More competitions in business make it difficult for businesses to survive. This is more evident in small and medium-size businesses where information technology and interactions seems crucial (Akbary, 2005).

There is a difference between entrepreneurs' concept of the role of computer in creating entrepreneurial opportunities and scores derived from this study. The results of Lai and Chen (2009) demonstrated the positive impact of e-business using the computer. In this research, a field study was conducted at six companies in Taiwan that manufactures a positive effect on the development of e-business, business environment has been demonstrated. Bagheri et al (2012) in a study entitled the role of ICT in developing entrepreneurial opportunities in line with the results of this research were presented. They concluded that ICT plays a positive role in developing entrepreneurial opportunities. In this paper, the purpose of ICT is a term for any type of communication device or application, such as: radio, television, cellular phones, computers, satellite systems and so on have been applied to the services, the variety of services and programs it is related. The results of the study Ndubisi and Kahraman (2005) showed that the women entrepreneurs make use of computer systems in business. The possible of reasons for the proposed studies is consistent with the study of computer use in business can be noted. Malhotra et.al (2012) presented different results of their findings indicated that mobile phone are creating more entrepreneurship than computers. The reasons for the difference mentioned research study can be explained by differences in the type of statistical populations. Human is subject to error due to his every day emotions. For instance man cannot handle numerous calculations all at the same time without making a mistake. But computers are capable of such doing not once but repeatedly; thus one could rely on computers for exactly correct outcome. Therefore using computers in businesses could lead to better quality and quantity and lower costs of manufacturing. As the role of computer fall behind other components, it is suggested that it is used so as to expand entrepreneurship.

Mobile Device is a device, typically electronic in nature, that can store large amounts of information and maybe easily transported from place to place without undue effort or cost. With mobile devices getting more widespread and technically advanced, potential business models have to be developed existing models need to be adapted.(Isckia et.al, 2011). Mobile phones are particularly suited to business users. They let you answer customer calls immediately, and reach staff or business contacts while you are working away from your business premises. A mobile phone will give you greater flexibility, faster customer response and time savings. Tariffs are higher for mobile phones, but they offer flexible charging options including pre-paid phones - where no up-front charges (deposit or monthly subscription) are required.The number of people using mobile phones has exceeded 5 billion, meaning that $3 / 4$ of people in the world use this small magical tool. In 75 countries mobile phones' penetration coefficient has well exceeded the population, meaning that one individual possesses more than one mobile phone (Hozer et.al, 2011). Compared with computers and internet, mobile phones are portable tools and provide easy access to and for the owner. Easy access to information while moving is the technological advantage of mobile phones. A study done by Malhotra et.al in 2012 show those mobile phones could be more useful to businesses than computers. The 
results coming from this study also show a meaningful difference between the entrapper's idea of the role of mobile phones in creating entrepreneurial opportunities and the score. wenhong Chen's study does not agree with such results. This could be down to the fact that wenhong Chen's study focused mainly on the role of internet on entrepreneurship. New communication devices such as mobile phones offer greater flexibility for keeping in touch with customers, suppliers and business contacts locally and in the region. As the role of mobile phones fall behind other components, it is suggested that it is used so as to expand entrepreneurship.

\section{Resources}

- $\quad$ Audretsch D. B, 2007. The entrepreneurial society. New York: Oxford University Press. pp 100110.

- Akbari H, 2005. An investigation into entrepreneurship obstacles in Shomal wood manufacturing company, MA essay in the field if state management in Tarbiat Modares university, Faculty of humanities pp 19-22.

- $\quad$ Baqeri Z, shiasy F, Maleki M, 2012. An investigation into the role of information technology and communication in expansion of entrepreneurship opportunities as seen by members of the board of education of Azad and Payam-e-Noor, National conference on entrepreneurship and business management and knowledge-based businesses. pp 48-59

- Ballon P, Walravens N, Spedalieri A, Venezia C, 2008. The Reconfiguration of Mobile Service Provision: Towards Platform Business Models.19th ITS European Regional Conference, Rome, Italy, URL http://ssrn.com/abstract=1331549

- Foroughipoor H, Mozafari A, Ashrafganjavi F, 2007. Evaluation and introduction of entrepreneurship priorities in sport as seen by activists in the field, Study in sport sciences. pp 58-69

- Fathian M and Mahdavinoor H, 2008. Principles and management of information technology, Industries and Sciences publishing .pp 167-171

- Gibbs J,Kraemer K, Dedrick J, 2003. Environment Policy Factors Shaping global E-Commerce Diffusion: A Cross-Country Comparison, Information Society, 19 (1), pp. 5- 18.

- Gerum E, Sjurts I, Stieglitz N, 2004. Industry Convergence and the Transformation of the Mobile Communications System of Innovation. ITS $15^{\text {th }}$ Biennial, Berlin, Conference Germany.pp 203223

- Hisrich R, Langan-Fox J, Grant S, 2007. Entrepreneurship research and practice: A call to action for psychology. American Psychologist, 62, pp 575-589.

- Holzer A, Ondrus J, 2011. Mobile Application Market: A Developer's Perspective. Telematics and Informatics, pp 22-31.

- Isckia T, Gueguen G, 2011. The Borders of Mobile Handset Ecosystems: Is Coopetition Inevitable? Telematics and Informatics, pp 5-11.

- Krueger N, 2007. What lies beneath? The experiential essence of entrepreneurial thinking. Entrepreneurship: Theory \& Practice, 31,pp 123-138.

- Karamipour M, 2003. Educational management in information age, educational technology, No 2,Theran,pp 3-7 
- Keser H, 2004. Ergonomik açidan bilgisayar çalima ortamlarinin düzenlenmesi [Organisation of computer working environments in terms of ergonomics]. XII. Educational Sciences Congress Proceedings, Volume 2, Ankara, pp 1219-1234

- Lai J \& Chen W, 2009. Measuring e-Business dependability: The employee perspective. The Journal of Systems and Software, pp 1046-1055.

- Malhotra A, Anjala K, Payal P, 2012. How mobile phones, Computer and internet can catalyze women's entrepeneurship (case study india), International center for research on women. pp $12-130$

- Madhoshi M,Safarinejad, 2004. E-commerce websites in Iran, strategies and models, quarterly of commercial studies.pp 71-81

- Montazer G, 2002. IT-based development as a futuristic view in the educational system of the country, quarterly of science and educational management in higher education. pp 97-104

- Mcqueen R. j, 2010. E-entrepreneurship : proposed use of the internet in a business plan competition in new zealand, department of management systems,pp 13-17

- $\quad$ Mondalizadeh Z, Honary H, 2010. An investigation into influential factors in entrepreneurship in sports, as an Interdisciplinary field area, quarterly of Interdisciplinary studies in humanities. pp 113-136

- $\quad$ Ndubisi N, Kahraman C, 2005. Malaysian women entrepreneurs: understanding the ICT usage behaviors and drivers. Journal of Enterprise Information Management; Volume: 18 Issue: 6; Research paper.

- Pelgrum, 2001. Obstacles to the integration of ICT in education: Results from a worldwide educational assessment. Computers \& Education, pp 163-178.

- $\quad$ Rais Dana H, 2002. The Instructional Technology,Tehran, pp 33-40

- Rudestam K.E, Silverman R, 2004. Encyclopaedia of distributed learning, California: sage publications, PP 232- 240

- Salimi j,Nikpoor, 2009. Internet-based interactions in life: An investigation into understanding social support and feeling of loneliness while using the internet,Tehran, journal of psychological and educational sciences of Alzahra University.pp 80-95

- $\quad$ Tinio V, 2006. ICT in Education, Preliminary Findings, 2002,pp. 6-8

- Wenhong Chen, The impact of internet use on transnatonal entrepreneurship, $4^{\text {th }}$ Coming in new technologies in global societies.pp 13-20 